2014, volume 3, issue 1

Bolibok P. (2014). The impact of IFRS on the value relevance of accounting data of banks listed on the Warsaw Stock Exchange. Copernican Journal of Finance \& Accounting, 3(1), 33-43. http:// dx.doi.org/10.12775/CJFA.2014.003

\title{
THE IMPACT OF IFRS ON THE VALUE RELEVANCE OF ACCOUNTING DATA OF BANKS LISTED ON THE WARSAW STOCK EXCHANGE
}

Key words: banks, value relevance, accounting standards.

J E L Classification: C23, G14, G21, M41.

Abstract: The paper aims at investigating the impact of IFRS on the value relevance of fundamental accounting data announced by banks listed on the Warsaw Stock Exchange over the period 1998-2012. Given the specificity of banking sector, the analyses were based on the Ohlson residual income valuation model. The empirical evidence indicates that observed increase in the value relevance of both book values of equity and residual incomes of banks after introduction of IFRS is statistically insignificant. The obtained results are, therefore, consistent with the findings of previous research conducted on non-financial enterprises in the context of Polish capital market.

\section{WPEYW MSSF NA ZNACZENIE DANYCH KSIĘGOWYCH DLA WARTOŚCI RYNKOWEJ BankóW NotoWANYCH Na WARSZaWSKIEJ GIEŁDZIE PAPIERóW WARTościoWYch}

Słowa kluczowe: banki, wartość rynkowa, standardy rachunkowości.

Klasyfikacja J E L: C23, G14, G21, M41.

Date of submission: March 3, 2014; date of acceptance: March 19, 2014.

* Contact information: piotr.bolibok@kul.pl, Faculty of Social Sciences, Department of Banking, The John Paul II Catholic University of Lublin, Al. Racławickie 14, 20-950 Lublin, Poland, phone: 814453433. 


\begin{abstract}
Abstrakt: Celem artykułu jest ocena wpływu MSSF na znaczenie fundamentalnych danych księgowych dla wartości rynkowej banków notowanych na Warszawskiej Giełdzie Papierów Wartościowych w okresie 1998-2012. Mając na uwadze specyfikę sektora bankowego, analizy zostały oparte na Ohlsona modelu zysków rezydualnych. Wyniki empiryczne wskazują, że obserwowany po wprowadzeniu MSSF wzrost znaczenia zarówno wartości księgowych kapitałów własnych, jak i rezydualnych wyników finansowych banków dla ich wyceny przez rynek kapitałowy jest nieistotny statystycznie. Uzyskane rezultaty są zatem spójne z wynikami dotychczasowych badań dotyczących przedsiębiorstw niefinansowych notowanych na polskim rynku kapitałowym.
\end{abstract}

Translated by Piotr Bolibok

\title{
INTRODUCTION
}

Since 2005 all publicly traded companies governed by the laws of member states of the European Union are obliged to prepare their consolidated accounts in conformity with the International Financial Reporting Standards (IFRS) (Regulation (EC) No. 1606/2002). This requirement is aimed at improvement of efficiency and cost-effectiveness of the EU capital market, by facilitating the freedom of capital movement, and fostering competition for financial resources among companies. Accession of Poland to the EU in May, 2004 required, among other things, complying with legislation on accounting standards. The provisions of Regulation No. 1606/2002 were, therefore, directly incorporated into the Polish Act on accounting (Act on accounting 1994).

IFRS are supposed to provide equity investors, with more useful information on the true financial position of companies, which in turn should lead to higher coherence between reported accounting data and market value of listed companies (Escaffre, Sefsaf 2011). A particularly interesting context for investigating these expectations is provided by the banking sector, due to a high homogeneity of business operations and liquidity of publicly traded shares.

Since the seminal study of Ball and Brown (1968), international literature on the value relevance of accounting data has become quite abundant. A recent line of research in this field is focused on the influence of IFRS adoption on value relevance of accounting information. The results of investigations conducted in various capital markets are mixed. Some studies report increase of value relevance after adoption of IFRS (Bartov, Goldberg, Kim 2005; Barth, Landsman, Lang 2008; Karampinis, Hevas 2009), while others fail to find any statistically significant improvements (Hung, Subramanyam 2007; Karampinis, Hevas 2011; Macias, Muiño 2011), or even suggest its decline (Khanagha 2011). 
The impact of IFRS on the value relevance of accounting data of non-financial enterprises in the context of Polish capital market was investigated by Dobija and Klimczak (2010) and Klimczak (2011). Their results also suggest no statistically significant improvement in the value relevance after the adoption of IFRS.

The aforementioned studies on the impact of IFRS on the value relevance of accounting information either exclude banks from the examined samples or include them without any separate consideration, hence, the empirical evidence in the specific context of banking sector is rather scarce.

Escaffre and Sefsaf (2011) conducted a comparative analysis of the value relevance of earnings and book values of equity across financial institutions, including banks, in the selected European markets and the US market over the period 2005-2008. Their results suggest that earnings and equity had greater value relevance in the European markets with IFRS than in the American market with US GAAP. Interestingly, all the examined European markets, except the Spanish one, exhibited a higher value relevance of book values than earnings, whereas in the US market, the results were exactly opposite.

A study by Anandarajan, Francis, Hasan and John (2011) conducted on banking institutions from 38 countries over the period 1993-2004 indicated that at the macro-level the value relevance of earnings and book values of equity is affected by disclosure requirements of a country's standards boards (the greater disclosure required, the more significant value relevance). They also found that value relevance is higher when the local environment is more focused on the private sector and the legal environment is more friendly to shareholders. In contrast to findings of Escaffre and Sefsaf (2011), Anandarajan et al. (2011) report a higher value relevance for British-American banks, which operate in regulatory regimes associated with greater levels of transparency.

Agostino, Drago and Silipo (2011) examined listed banks from 15 EU countries over the period 2000-2006, finding that the introduction of IFRS enhanced the information content of earnings and book value for more transparent banks, but the less transparent entities did not experience any significant increase in the value relevance.

It appears that to date no studies have addressed the problem of impact of IFRS on the value relevance of banks' accounting information in the context of Polish banking sector. Ambiguous results of international studies, and the evidence from the Polish capital market for non-financial companies, have therefore led to formulation of the main hypothesis of the present study: 
HYPOTHESIS 1. The value relevance of accounting information announced by banks listed on the WSE did not improve after implementation of IFRS.

The scope of this paper is to examine the impact of IFRS implementation on the value relevance of fundamental accounting information announced by banks in the context of emerging capital market of Poland. The study seems to be the first attempt to address this issue and it seeks to fill this apparent gap. An additional contribution of the paper is enhancement of the existing, relatively scarce, international literature on the impact of IFRS on the value relevance of banks' accounting information.

The remainder of the paper is composed of two sections. Section 2 describes the data sources, research methods, and the design of the research process. The main findings and conclusions of the study are presented in section 3 .

\section{THE RESEARCH METHODOLOGY AND THE COURSE OF THE RESEARCH PROCESS}

The research was based on the data of all domestically-based commercial banks listed on the WSE over the period 1998-2012, which prepared the consolidated financial statements. Due to mergers and acquisitions the final sample consisted of 17 banks. The data on consolidated annual financial statements was obtained from the Notoria Serwis SA database provided by ISI Emerging Markets (http://site.securities.com 2013), whereas data on stock prices from the website of Gazeta Gieldy Parkiet (http://www.parkiet.com 2013). The combined data on book values, net earnings, and stock prices yielded the final pooled sample of 174 bank-year observations. The data on the average yield of 52-week treasury bills (taken as a risk-free in calculation of residual incomes), was obtained from the website of the Polish Ministry of Finance (http://www. mf.gov.pl 2013).

The research framework of the study was based on the Ohlson (1995) residual income model. The model is based on three main assumptions (Ohslon 1995, 663-664). First, in accordance with neoclassical models of security valuation, the market value of a company is determined by the present value of expected dividends. Second, the model assumes existence of the rules of clean surplus accounting, where all changes in the book value of equity are reflected in earnings or transactions with the owners of a company. Third, residual incomes (net earnings minus a charge for the use of capital) follow a stochastic process referred to as linear information dynamics, specifying that following period's residual income is linearly dependent on residual income from previous 
period with correction for the impact of non-accounting information. Basing on these assumptions all value-relevant events should be captured by current or expected future earnings and book values.

Following the approach by Bernard (1995), the Ohlson model can be applied to empirical tests through a linear regression analysis with the ordinary least squares method. Focusing only on banking industry, that exhibits a high degree of homogeneity in operations, reduces cross-sectional variation in factors that might affect estimates of models' parameters (Beaver, Eger, Ryan, Wolfson 1989; Beaver, McAnally, Stinson 1997).

Main advantages of the Ohlson (1995) model for examining the value relevance of accounting information are its strong embedment in the neoclassical theory of finance, simplicity, and the results of many empirical studies conducted in the developed capital markets, indicating its usefulness. Although most of those studies exclude banks from the examined samples of companies, the model appears particularly appropriate for testing the value relevance in the context of banking sector (Kohlbeck, Warfield 2007, 24). It should be noticed, however, that the model has also some limitations resulting from simplifying assumption that the owners of companies expect a risk-free rate of return on invested capital.

To investigate the relationship between fundamental accounting information announced by banks and their market value, the following multiple regression function was used:

$$
\tilde{p}_{t}=\alpha_{0}+\alpha_{1} \cdot b_{t}+\alpha_{2} \cdot x_{t}^{a}+\varepsilon_{t}
$$

where:

$$
\begin{aligned}
\tilde{p}_{t} & - \text { closing price of a bank's share at the end of period } t ; \\
\alpha_{0} & - \text { intercept; } \\
\alpha_{1}, \alpha_{2}- & \text { structural parameters; } \\
b_{t}- & \text { consolidated book value per share at the end of period } t, \\
x_{t}^{a}=x_{t}-r_{f_{t-1}} \cdot b_{t-1}- & \text { consolidated residual income per share at the end of period } \\
& t \text {, where } r_{f t-1} \text { is a risk-free rate at the end of period } t-1 ; \\
\varepsilon_{t} & - \text { error term. }
\end{aligned}
$$

The calculation of residual incomes was based on the original Ohlson's (1995) approach, which assumes that the owners of companies expect a risk- 
free rate of return on invested capital. The risk-free rate was taken as the average annual yield of the Polish 52-week treasury bills.

The estimates of parameters $\alpha_{1}$ and $\alpha_{2}$ are expected to be positive. The presence of error term serves for capturing the influence of potential factors not included in the model.

In order to investigate the impact of IFRS on value relevance of accounting information published by the banks, in accordance with the approach proposed by Karğin (2013), the following regression was applied:

$$
\tilde{p}_{t}=\alpha_{0}+\alpha_{D 0} \cdot D_{t}+\alpha_{1} \cdot b_{t}+\alpha_{2} \cdot x_{t}^{a}+\alpha_{3} \cdot\left(D_{t} \cdot b_{t}\right)+\alpha_{4} \cdot\left(D_{t} \cdot x_{t}^{a}\right)+\varepsilon_{t}
$$

where: $D_{t}$ is a dummy variable equal 0 for $t=1998,1999, \ldots ., 2004$ and 1 for $t=2005,2006, \ldots, 2012$.

Estimates of structural parameters $\alpha_{3}$ and $\alpha_{4}$ in equation (2) represent the differences in values of coefficients of consolidated book value of equity and residual income per share, respectively, before and after implementation of IFRS. The positive (negative) values of these parameters indicate increase (decrease) of the value relevance of corresponding accounting data after implementation of IFRS.

To test the statistical significance of the differences in regression coefficients before and after the adoption of IFRS in Poland the Chow test for structural change was used. The Chow test statistic is given by the following equation (Dougherty 2001, 245-246):

$$
F(k, n-2 k)=\frac{\left(R S S_{P}-R S S_{A}-R S S_{B}\right)}{\left(R S S_{A}+R S S_{B}\right) /(n-2 k)}
$$

where:

$\mathrm{RSS}_{\mathrm{P}}$ - total sum of the squares of the residuals in the pooled regression,

$\mathrm{RSS}_{\mathrm{A}}, \mathrm{RSS}_{\mathrm{B}}$ - residual sums of squares for the subsample regressions A and B, respectively,

$\mathrm{n}$ - number of observations in the pooled sample,

$\mathrm{k}$ - number of regression coefficients.

The Chow test statistic follows the F distribution with $(k, n-2 k)$ degrees of freedom. The null hypothesis of the test is that the regression coefficients 
in the both subsamples are exactly the same. If the estimated value of the test statistic exceeds the corresponding critical value of the F distribution, then the null hypothesis is rejected indicating occurrence of the structural break in the regression parameters, i.e. a statistically significant difference between regression coefficients in each subsample.

\section{THE OUTCOME OF THE RESEARCH PROCESS AND CONCLUSIONS}

The data in Table 1 presents the results of estimation of the equation (1) for the years preceding (1998-2004) and succeeding (2005-2012) the introduction of IFRS in Poland, as well as for the whole analysed period.

Table 1. Estimations of residual income valuation model parameters for commercial banks listed on the WSE before and after implementation of IFRS

\begin{tabular}{|c|c|c|c|c|c|c|c|c|c|}
\hline \multirow{4}{*}{ Parameter } & \multicolumn{9}{|c|}{ Model: $\tilde{p}_{t}=\alpha_{0}+\alpha_{1} \cdot b_{t}+\alpha_{2} \cdot x_{t}^{a}+\varepsilon_{t}$} \\
\hline & \multicolumn{9}{|c|}{ Period } \\
\hline & \multicolumn{3}{|c|}{ 1998-2004 } & \multicolumn{3}{|c|}{$2005-2012$} & \multicolumn{3}{|c|}{$1998-2012$} \\
\hline & $\begin{array}{l}\text { Estimate/ } \\
\text { value }\end{array}$ & $\begin{array}{l}\text { Std. } \\
\text { error }\end{array}$ & $p$-value & $\begin{array}{c}\text { Estimate/ } \\
\text { value }\end{array}$ & $\begin{array}{l}\text { Std. } \\
\text { Error }\end{array}$ & $p$-value & $\begin{array}{c}\text { Estimate/ } \\
\text { value }\end{array}$ & $\begin{array}{l}\text { Std. } \\
\text { Error }\end{array}$ & p-value \\
\hline$\alpha 0$ & 0.726 & 4.723 & 0.878 & -0.401 & 9.816 & 0.968 & -0.115 & 6.310 & 0.986 \\
\hline$\alpha 1$ & 1.646 & 0.054 & 0.000 & 1.663 & 0.144 & 0.000 & 1.724 & 0.072 & 0.000 \\
\hline$\alpha 2$ & 2.660 & 0.504 & 0.000 & 5.143 & 1.186 & 0.000 & 4.289 & 0.570 & 0.000 \\
\hline $\operatorname{Adj} . R^{2}$ & 0.931 & & & 0.842 & & & 0.859 & & \\
\hline F-statistic & 457.118 & & 0.000 & 278.796 & & 0.000 & 525.942 & & 0.000 \\
\hline$N$ & 69 & & & 105 & & & 174 & & \\
\hline
\end{tabular}

S o u r c e : own elaboration.

Consistent with expectations, the results of analysis show that all estimated regression coefficients were positive and statistically significant. In general, the responsiveness of banks' market value to changes in residual income was higher than to variation in book values. Over the whole analysed period an increase in the book value per share of 1 PLN resulted in an average increase of the share price of 1.7 PLN, whereas the same increase in residual income per share caused a 4.3 PLN increase in the price. 
In general, the comparison of the regression coefficients in each of the analysed subperiods suggests an increase in the value relevance of accounting information announced by banks listed on the WSE after introduction of IFRS. However, the magnitude of this increase for book values of equity and residual incomes was quite different. The responsiveness of banks' market value to changes in book value of their equity in both analysed subperiods was very similar. On average, an increase in book value per share of 1 PLN resulted in an increase in the price of bank share of about 1.6-1.7 PLN. Conversely, the difference in the values of regression coefficients for residual income was much higher. Before introduction of IFRS in Poland 1 PLN increase in residual income per share caused an average increase in the share price of 2.7 PLN, while after their implementation the analogous increase exceeded 5.1 PLN. The decrease in the value of adjusted regression coefficient of determination indicates, however, that the descriptive power of the whole model declined in the period succeeding the implementation of IFRS. These ambiguous results required further analytical investigation with the Chow test for structural change (Table 2).

Table 2. Chow test for structural change in value relevance of banks' consolidated accounting data after implementation of IFRS

\begin{tabular}{|c|c|c|c|}
\hline \multicolumn{4}{|c|}{ Model: $\tilde{p}_{t}=\alpha_{0}+\alpha_{D 0} \cdot D_{t}+\alpha_{1} \cdot b_{t}+\alpha_{2} \cdot x_{t}^{a}+\alpha_{3} \cdot\left(D_{t} \cdot b_{t}\right)+\alpha_{4} \cdot\left(D_{t} \cdot x_{t}^{a}\right)+\varepsilon_{t}$} \\
\hline Parameter & Estimate/value & Std. error & $p$-value \\
\hline$\alpha 0$ & 0.726 & 10.282 & 0.944 \\
\hline$\alpha D O$ & -1.127 & 13.020 & 0.931 \\
\hline$\alpha 1$ & 1.646 & 0.119 & 0.000 \\
\hline$\alpha 2$ & 2.660 & 1.097 & 0.016 \\
\hline$\alpha 3$ & 0.017 & 0.167 & 0.917 \\
\hline$\alpha 4$ & 2.483 & 1.461 & 0.091 \\
\hline Adj. $R 2$ & 0.859 & & \\
\hline F-statistic & 211.269 & & 0.000 \\
\hline Chow test statistic & 1.068 & & 0.364 \\
\hline N1 (1998-2004) & 69 & & \\
\hline
\end{tabular}




\begin{tabular}{|c|c|c|c|}
\hline \hline \multicolumn{4}{|c|}{ Model: $\underline{\tilde{p}_{t}=\alpha_{0}+\alpha_{D 0} \cdot D_{t}+\alpha_{1} \cdot b_{t}+\alpha_{2} \cdot x_{t}^{a}+\alpha_{3} \cdot\left(D_{t} \cdot b_{t}\right)+\alpha_{4} \cdot\left(D_{t} \cdot x_{t}^{a}\right)+\varepsilon_{t}}$} \\
\hline Parameter & Estimate/value & Std. error & $p$-value \\
\hline \hline N2 (2005-2012) & 105 & & \\
\hline \hline
\end{tabular}

S o u r c e : own elaboration.

The results of estimation of the equation (2) presented in the Table 2 are consistent with the previous findings. Positive values of regression coefficients estimates $\alpha_{3}$ and $\alpha_{4}$ indicate that both book values and residual incomes became more value relevant after the introduction of IFRS. Each of these estimates, however, turned out to be insignificant at the $5 \%$ significance level. The $p$-value for the coefficient estimate $\alpha_{4}$ indicates that the increase in the value relevance of residual incomes would be significant at the $10 \%$ significance level.

The estimated Chow test statistic equalled 1.068 which turned out to be lower than the corresponding critical value of the F distribution (2.658). This indicates a failure to reject the null hypothesis of exactly no difference in regression coefficients between the analysed subperiods and suggests a lack of sufficient evidence on structural break in parameters of the model. In other words, the observed increase in the value relevance of banks' accounting information after introduction of IFRS in Poland was statistically insignificant, which supports the main hypothesis of the present study.

The conducted analyses, based on the Ohlson residual income model, support the key hypothesis developed in the present study, and indicate that the implementation of IFRS in Poland did not have a statistically significant impact on the value relevance of fundamental accounting data announced by the banks listed on the Warsaw Stock Exchange.

The Chow test for structural change revealed that an increase in the responsiveness of banks' market value to variations in book values of equity and residual incomes after introduction of IFRS turned out to be statistically insignificant. The findings for the banking sector are, therefore, consistent with the results of previous studies conducted in the context of Polish capital market on non-financial firms.

It appears, that for equity investors, the quality of financial reporting under Polish accounting standards was not inferior to potentially more informative IFRS. In the particular context of banking sector this observation might be attributable to the specificity of banking operations and their recognition in financial statements that result in coherence of capital market's and accounting 
perspectives even under less advanced standards. On the other hand, the results of the research suggest the necessity of further improvement of financial reporting quality in order to make it more useful for equity investors.

\section{REFERENCES}

Act of 29 September 1994 on accounting. J. L. 2013, item 330, 613.

Agostino M., Drago D., Silipo D. B. (2011). The value relevance of IFRS in the European banking industry. Review of Quantitative Finance and Accounting, 36 (3), 437-457. http://dx.doi.org/10.1007/s11156-010-0184-1.

Anandarajan A., Francis B., Hasan I., John K. (2011). Value relevance of banks: Global evidence. Review of Quantitative Finance and Accounting, 36 (1), 33-55. http://dx.doi. org/10.1007/s11156-010-0170-7.

Ball R., Brown P. (1968). An empirical evaluation of accounting income numbers. Journal of Accounting Research, 6 (2), 159-178.

Barth M. E., Landsman W. R., Lang M. H (2008). International Accounting Standards and accounting quality. Journal of Accounting Research, 46 (3), 467-498. http://dx.doi. org/10.1111/j.1475-679X.2008.00287.x.

Bartov E., Goldberg S., Kim M. (2005). Comparative value relevance among German, US, and international accounting standards: A German stock market perspective. Journal of Accounting, Auditing \& Finance, 20 (2), 95-119. http://dx.doi.org/10.1177 /0148558X0502000201.

Beaver W. H., Eger C., Ryan S., Wolfson M. (1989). Financial reporting, supplemental disclosures, and bank share prices. Journal of Accounting Research, 27 (2), 157-178.

Beaver W. H., McAnally M. L., Stinson C. H. (1997). The information content of earnings and prices: A simultaneous equations approach. Journal of Accounting and Economics 23 (1), 53-81. http://dx.doi.org/10.1016/S0165-4101(96)00424-7.

Bernard V. L. (1995). The Feltham-Ohlson framework: Implications for empiricists. Contemporary Accounting Research, 11 (2), 733-747. http://dx.doi.org/10.1111 /j.1911-3846.1995.tb00463.x.

Dobija D., Klimczak K. M. (2010). Development of accounting in Poland: Market efficiency and the value relevance of reported earnings. The International Journal of Accounting, 45 (3), 356-374. http://dx.doi.org/10.1016/j.intacc.2010.06.010.

Dougherty C. (2011), Introduction to econometrics, $4^{\text {th }}$ edition, Oxford University Press Inc., New York, 245-249.

Escaffre L., Sefsaf R. (2011). Comparing the value relevance of earnings and book value in IFRS and GAAP standards. Bankers. Markets and Investors, 114, 4-18.

http://site.securities.com/cgi-bin/comp_profiles/94dec/PL/comp_profiles.html(accessed: 30.12.2013).

http://www.mf.gov.pl/documents/766655/1185844/bonyskarbowe.xls (accessed: 30.12. 2013).

http://www.parkiet.com/pscHtmlData/dane/dane_atxt.jsp (accessed: 25.04.2013). 
Hung M., Subramanyam K. R. (2007). Financial statement effects of adopting international accounting standards: The case of Germany. Review of Accounting Studies, 12, 623-657. http://dx.doi.org/10.1007/s11142-007-9049-9.

Karampinis N. I., Hevas D. L. (2009). The effect of the mandatory application of IFRS on the value relevance of accounting data: Some evidence from Greece. European Research Studies, 12 (1), 73-100.

Karampinis N. I., Hevas D. L. (2011). Mandating IFRS in an unfavorable environment: The Greek experience. The International Journal of Accounting, 46, 304-332. http:// dx.doi.org/10.1016/j.intacc.2011.07.001.

Karğin S. (2013). The impact of IFRS on the value relevance of accounting information: Evidence from Turkish firms. International Journal of Economics and Finance, 5 (4), 71-80. http://dx.doi.org/10.5539/ijef.v5n4p71.

Khanagha J. B. (2011). Value relevance of accounting information in the United Arab Emirates. International Journal of Economics and Financial Issues, 1 (2), 33-45.

Klimczak K. M. (2011). Market reaction to mandatory IFRS adoption: Evidence from Poland. Accounting and Management Information Systems, 10 (2), 228-248.

Kohlbeck M., Warfield T. D. (2007). Unrecorded intangible assets: Abnormal earnings and valuation. Accounting Horizons, 21 (1), 23-41. http://dx.doi.org/10.2308/ acch.2007.21.1.23.

Macías M., Muiño F. (2011). Examining Dual Accounting Systems in Europe. The International Journal of Accounting, 46 (1), 51-78. http://dx.doi.org/10.1016/j.intacc.2010.12.001.

Ohlson J. A. (1995). Earnings, book values and dividends in equity valuation. Contemporary Accounting Research, 11 (2), 661-687. http://dx.doi.org/10.1111/j.1911-3846.1995. tb00461.x.

Regulation (EC) No. 1606/2002 of the European Parliament and of the Council of 19 July 2002 on the application of the international accounting standards. Official Journal of the European Communities. L 243, 19.07.2002. 
